\title{
Front Matter: Volume 10422
}

, "Front Matter: Volume 10422," Proc. SPIE 10422, Remote Sensing of the Ocean, Sea Ice, Coastal Waters, and Large Water Regions 2017, 1042201 (7 November 2017); doi: 10.1117/12.2293011 


\title{
PROCEEDINGS OF SPIE
}

\section{Remote Sensing of the Ocean, Sea Ice, Coastal Waters, and Large Water Regions 2017}

\author{
Charles R. Bostater Jr. \\ Stelios P. Mertikas \\ Xavier Neyt \\ Sergey Babichenko \\ Editors \\ 11-12 September 2017 \\ Warsaw, Poland \\ Sponsored by \\ SPIE \\ Cooperating Organisations \\ Innovation Centre for Sensor and Imaging Systems (United Kingdom) \\ ADS Scotland (United Kingdom) \\ The Knowledge Transfer Network (United Kingdom) \\ Visit Scotland (United Kingdom) \\ European Regional Development Fund (Belgium) \\ Technology Scotland (United Kingdom) \\ European Association of Remote Sensing Companies (Belgium) \\ European Association of Remote Sensing Laboratories (Germany) \\ The British Association of Remote Sensing Companies (United Kingdom) \\ Remote Sensing \& Photogrammetry Society (United Kingdom) \\ Published by \\ SPIE
}

Volume 10422 
The papers in this volume were part of the technical conference cited on the cover and title page. Papers were selected and subject to review by the editors and conference program committee. Some conference presentations may not be available for publication. Additional papers and presentation recordings may be available online in the SPIE Digital Library at SPIEDigitalLibrary.org.

The papers reflect the work and thoughts of the authors and are published herein as submitted. The publisher is not responsible for the validity of the information or for any outcomes resulting from reliance thereon.

Please use the following format to cite material from these proceedings:

Author(s), "Title of Paper," in Remote Sensing of the Ocean, Sea Ice, Coastal Waters, and Large Water Regions 2017, edited by Charles R. Bostater Jr., Stelios P. Mertikas, Xavier Neyt, Sergey Babichenko, Proceedings of SPIE Vol. 10422 (SPIE, Bellingham, WA, 2017) Seven-digit Article CID Number.

ISSN: 0277-786X

ISSN: 1996-756X (electronic)

ISBN: 9781510613089

ISBN: 9781510613096 (electronic)

Published by

SPIE

P.O. Box 10, Bellingham, Washington 98227-0010 USA

Telephone +1 3606763290 (Pacific Time) · Fax +1 3606471445

SPIE.org

Copyright (C) 2017, Society of Photo-Optical Instrumentation Engineers.

Copying of material in this book for internal or personal use, or for the internal or personal use of specific clients, beyond the fair use provisions granted by the U.S. Copyright Law is authorized by SPIE subject to payment of copying fees. The Transactional Reporting Service base fee for this volume is $\$ 18.00$ per article (or portion thereof), which should be paid directly to the Copyright Clearance Center (CCC), 222 Rosewood Drive, Danvers, MA 01923. Payment may also be made electronically through CCC Online at copyright.com. Other copying for republication, resale, advertising or promotion, or any form of systematic or multiple reproduction of any material in this book is prohibited except with permission in writing from the publisher. The CCC fee code is 0277$786 \mathrm{X} / 17 / \$ 18.00$.

Printed in the United States of America.

Publication of record for individual papers is online in the SPIE Digital Library.

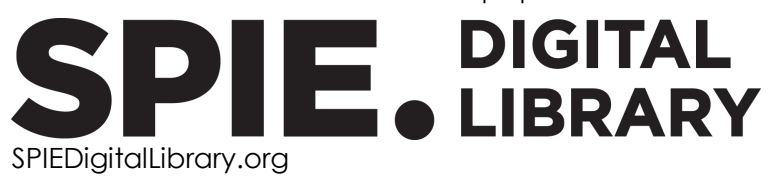

Paper Numbering: Proceedings of SPIE follow an e-First publication model. A unique citation identifier (CID) number is assigned to each article at the time of publication. Utilization of CIDs allows articles to be fully citable as soon as they are published online, and connects the same identifier to all online and print versions of the publication. SPIE uses a seven-digit CID article numbering system structured as follows:

- The first five digits correspond to the SPIE volume number.

- The last two digits indicate publication order within the volume using a Base 36 numbering system employing both numerals and letters. These two-number sets start with $00,01,02,03$, 04, 05, 06, 07, 08, 09, OA, OB ... 0Z, followed by 10-1Z, 20-2Z, etc. The CID Number appears on each page of the manuscript. 


\title{
Contents
}

\author{
vii Authors \\ ix Conference Committee \\ xi Introduction
}

SESSION 1 OIL SPILL SENSING, SURVEILLANCE, AND LASERS

1042202 Real-time surveillance system for marine environment based on HLIF LiDAR (Invited Paper) [10422-1]

1042203 Vessel and oil spill early detection using COSMO satellite imagery [10422-2]

1042204 Radar and optical remote sensing in offshore domain to detect, characterize, and quantify ocean surface oil slicks [10422-3]

1042205 Oil spill detection from TerraSAR-X dual-polarized images using artificial neural network [10422-4]

\section{SESSION 2 SHALLOW WATER SENSING OF COASTAL WATERS, HABITATS, AND TARGETS}

1042208 Shallow water bathymetry correction using sea bottom classification with multispectral satellite imagery [10422-8]

1042209 Collection and corrections of oblique multiangle hyperspectral bidirectional reflectance imagery of the water surface [10422-9]

\section{SESSION $3 \quad$ WATER QUALITY RELATED SENSING}

10422 OB Grain size mapping in shallow rivers using spectral information: a lab spectroradiometry perspective (Best Student Paper) [10422-11]

10422 OE Hyperspectral signatures and WorldView-3 imagery of Indian River Lagoon and Banana River Estuarine water and bottom types [10422-63]

\section{SESSION $4 \quad$ AEROSOL AND POLARIZATION STUDIES}

10422 OF Imaging of polarized target in underwater environment [10422-18]

10422 OG Experimental study of dual polarized radar return from the sea surface [10422-17] 
$10422 \mathrm{OH}$ Characterization of aerosol parameters over ocean from the Ocean Color satellite sensors and AERONET-OC data [10422-19]

\section{SESSION 5 AIRBORNE AND SATELLITE SENSING OF WATER, SST, AND FRONTS}

10422 Ol Oil spill characterization thanks to optical airborne imagery during the NOFO campaign 2015 (Invited Paper) [10422-20]

$104220 \mathrm{~J}$ Revealing the timing of ocean stratification using remotely sensed ocean fronts [10422-21]

10422 OK Identifying pancake ice and computing pancake size distribution in aerial photographs [10422-22]

$10422 \mathrm{OL}$ Long-term monitoring of sea ice conditions in the Kerch Strait by remote sensing data [10422-23]

\section{SESSION 6 REMOTE SENSING OF VESSELS, WATER CIRCULATION, AND TIDES}

10422 OM Surface circulation in the Western Mediterranean shown by a synergy of satellite-derived datasets [10422-25]

10422 ON A parallel efficient partitioning algorithm for the statistical model of dynamic sea clutter at low grazing angle [10422-26]

\section{SESSION 7 ALTIMETRY, SAR, MICROWAVE, AND POLARIZATION SENSING}

10422 OR Ensuring that the Sentinel-3A altimeter provides climate-quality data [10422-30]

10422 OS Multifrequency radar imagery and characterization of hazardous and noxious substances at sea [10422-31]

10422 OT Assessing altimetry close to the coast [10422-33]

10422 OU Coastline detection with time series of SAR images [10422-34]

\section{POSTER SESSION}

10422 OV Assessment of the quality of HY-2A satellite sea surface height data [10422-32]

10422 OX Ocean subsurface particulate backscatter estimation from CALIPSO spaceborne lidar measurements [10422-36]

10422 OY Laser induced fluorescence technique for detecting organic matter in East China Sea [10422-37]

$104220 Z$ Satellite observations of rainfall effect on sea surface salinity in the waters adjacent to Taiwan [10422-39] 
1042211 The artificial object detection and current velocity measurement using SAR ocean surface images [10422-42]

1042213 The re-analysis for satellite retrieved chlorophyll-a in East China Sea [10422-44]

1042214 Unusual phytoplankton blooms in the southwestern Bay of Bengal: a comparative study [10422-45]

1042215 Multi-sensor satellite survey of natural oil slicks in the southeastern Black Sea [10422-46]

1042216 Longtime variation of phytoplankton in the South China Sea from the perspective of carbon fixation [10422-47]

1042217 Retrieval of total suspended particulate matter in highly turbid Hangzhou Bay waters based on geostationary ocean color imager [10422-49]

1042218 Satellite remote sensing of the aquatic $\mathrm{pCO}_{2}$ in the basin of the South China Sea [10422-50]

$10422 \mathrm{lE}$ The influence of tide on sea surface temperature in the marginal sea of northwest Pacific Ocean [10422-57]

$104221 \mathrm{G}$ Satellite observation of the recent changes of chlorophyll in the South China Sea and Bay of Bengal [10422-59]

$104221 \mathrm{H}$ Damping of surface waves due to oil emulsions in application to ocean remote sensing [10422-60]

1042211 Utilization of multi-channel ocean LiDAR data to classify the types of waveform [10422-61]

$104221 \mathrm{~K}$ Intersatellite comparisons and evaluations of three ocean color products along the Zhejiang coast, eastern China [10422-48] 
Proc. of SPIE Vol. 10422 1042201-6

Downloaded From: https://www.spiedigitallibrary.org/conference-proceedings-of-spie on 26 Apr 2023 Terms of Use: https://www.spiedigitallibrary.org/terms-of-use 


\section{Authors}

Numbers in the index correspond to the last two digits of the seven-digit citation identifier (CID) article numbering system used in Proceedings of SPIE. The first five digits reflect the volume number. Base 36 numbering is employed for the last two digits and indicates the order of articles within the volume. Numbers start with 00, 01, 02, 03, 04, 05, 06, 07, 08, 09, OA, OB...0Z, followed by 10-12, 20-2Z, etc.

\author{
Abdalla, S., OR, OT \\ Ahmed, Sam, $\mathrm{OH}$ \\ Aleksejev, Valeri, 02 \\ Alpatov, Boris, 11 \\ Angelliaume, S., 04, Ol, OS \\ Ao, Dongyang, OU \\ Arnone, Robert, $\mathrm{OH}$ \\ Aziz, Samin, OE \\ Babichenko, Sergey, 02 \\ Bai, Yan, 14, 16, 18, 1G \\ Baker, S., OR \\ Baqué, R., 04 \\ Bocharova, Tatiana Yu., OL \\ Bonnefond, P., OR \\ Bostater, Charles R., 09, 0E \\ Brockley, D., OR \\ Callahan, Kelby, $\mathrm{OE}$ \\ Calmant, S., OR \\ Cancet, M., OR \\ Carrizo, Carlos, OF \\ Ceamanos, X., 04, 01 \\ Chataing, S., OS \\ Chen, Peng, OX, OY, 17, 11 \\ Chen, Tieqiao, 17 \\ Chen, Xiaoyan, 14, 16, 18, 1G \\ Conley, D., OT \\ Cretaux, J.-F., OR \\ Cui, Qiyuan, 1K \\ Datcu, Mihai, OU \\ Déliot, Ph., 04 \\ Delrieux, Claudio A., 03 \\ Dumitru, Octavian, OU \\ El-Habashi, Ahmed, OF \\ Ermakov, S. A., OG, $1 \mathrm{H}$ \\ Ershov, Maksim, 11 \\ Feldman, Alexander, 11 \\ Femenias, P., OR \\ Foster, Robert, $\mathrm{OF}, \mathrm{OH}$ \\ Frery, M.-L., OR \\ Gao, Xuemin, OV \\ Garcia, P., OR \\ Gilerson, Alex, $\mathrm{OF}, \mathrm{OH}$ \\ Gong, Fang, 13, 16, 18, 1G, 1K \\ Gray, Deric, OF \\ Gross, Barry, $\mathrm{OH}$ \\ Guerrieri, Lorenzo, OK \\ Hao, Zengzhou, 13, 17, $1 \mathrm{~K}$ \\ $\mathrm{He}$, Xianqiang, 13, 14, 17 \\ $\mathrm{He}, \mathrm{Y} ., \mathrm{ll}$
}

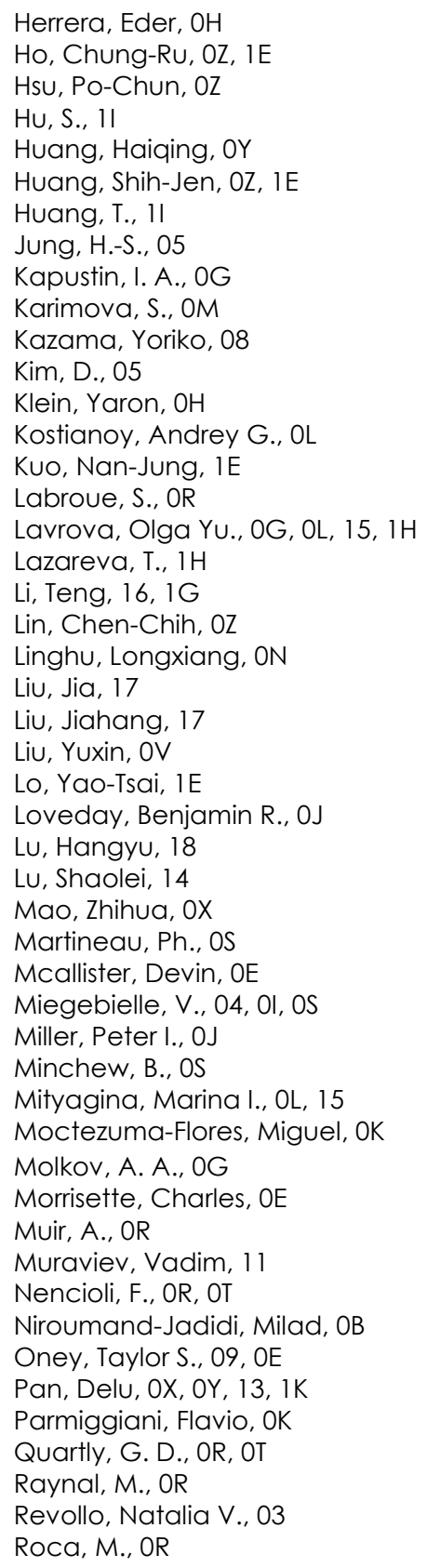


Rotkiske, Tyler, OE

Scharroo, R., OR

Schwarz, Gottfried, OU

Sergievskaya, I. A., OG, IH

Shepherd, A., OR

Shomina, O. V., OG

Smirnov, Sergey, 11

Sobolev, Innokenti, 02

Song, Qingtao, OV

Sõro, Oliver, 02

Strotov, Valery, 11

Tao, B., 11

Tsai, Yun-Chan, 1E

Viallefont-Robinet, F., 04, 0

Vitti, Alfonso, OB

Wang, C., 11

Wang, Difeng, 13, 16, 18, $1 \mathrm{~K}$

Wang, Tianyu, OX, OY, 1G, IK

Wang, Yihao, 17

Wang, Zhaohui, OV

Wu, Tao, ON

Wu, Zhensen, ON

XU, G., 11

Yamamoto, Tomonori, 08

Yu, J., 11

Yu, Shujie, 14, $1 \mathrm{G}$

Zhu, Feng, 17

Zhu, Qiankun, 16, 18, 1G, 1K 


\title{
Conference Committee
}

\author{
Symposium Chair
}

Klaus Schäfer, (Retired) Karlsruhe Institute of Technology, Institute of Meteorology and Climate Research (Germany)

Symposium Co-chair

Christopher M. U. Neale, University of Nebraska-Lincoln

(United States), Daugherty Water for Food Institute (United States)

Conference Chairs

Charles R. Bostater, Jr., Florida Institute of Technology (United States)

Stelios P. Mertikas, Technical University of Crete (Greece)

Xavier Neyt, Royal Military Academy (Belgium)

Sergey Babichenko, LDI Innovation/Ocean Visuals (Norway)

Conference Programme Committee

Richard J. Breitlow, Agfa Corporation (United States)

Jean-Paul Bruyant, ONERA (France)

Stephen Sun Chiao, San José State University (United States)

Alexander Gilerson, The City College of New York (United States)

Carlton R. Hall, NASA Kennedy Space Center (United States)

Frederic Lamy, ONERA (France)

Ana M. Martins, Universidade dos Açores (Portugal)

Petri Pellikka, University of Helsinki (Finland)

Session Chairs

1 Oil Spill Sensing, Surveillance, and Lasers

Sergey Babichenko, LDI Innovation/Ocean Visuals (Norway)

2 Shallow Water Sensing of Coastal Waters, Habitats, and Targets

Charles R. Bostater, Jr., Florida Institute of Technology (United States)

3 Water Quality Related Sensing

Charles R. Bostater, Jr., Florida Institute of Technology (United States))

4 Aerosol and Polarization Studies

Alexander Gilerson, The City College of New York (United States) 
5 Airborne and Satellite Sensing of Water, SST, and Fronts Françoise Viallefont, ONERA (France)

6 Remote Sensing of Vessels, Water Circulation, and Tides Xavier Neyt, Royal Military Academy (Belgium)

$7 \quad$ Altimetry, SAR, Microwave, and Polarization Sensing Graham Quartly, Plymouth Marine Laboratory (United Kingdom) Peter I. Miller, Plymouth Marine Laboratory (United Kingdom) 


\section{Introduction}

The chairs of Remote Sensing of the Ocean \& Sea Ice and Large Water Regions thank the authors of the papers reviewed and accepted for publication in this book. This book as well as the conference held in Warsaw, Poland introduced new authors, including students to new research and applications of many aspects of ocean optics and remote sensing of water. We appreciate the extra effort to submit their papers for consideration to be included in the published proceedings. The published articles in this book represent contributions that will be useful to help improve our knowledge and scientific understanding of remote sensing, physical oceanography, ocean engineering, ocean and coastal optics and ocean sciences in general. In many cases the accepted papers represent significant efforts of our colleagues to document their work and to share their understanding and experience through formal questions and informal discussions at the meeting.

We thank the session chairs for their extra work, participation and assistance with the conducting the meetings. As always special thanks go to the efforts of the SPIE staff for organizing the conference and for their assistance in reviewing and producing this final publication. Without SPIE's dedicated editorial support, this book could not be produced.

Charles R. Bostater Jr. Stelios P. Mertikas Xavier Neyt Sergey Babichenko 
Proc. of SPIE Vol. 10422 1042201-12 Downloaded From: https://www.spiedigitallibrary.org/conference-proceedings-of-spie on 26 Apr 2023
Terms of Use: https://www.spiedigitallibrary.org/terms-of-use 